\title{
A DESCRIPTIVE STUDY ON THE FINANCIAL FRAUD MANAGEMENT AND RISING FINANCIAL FLOWS IN INDIA
}

\author{
Arya V.S \\ Research Scholar \\ School of Management Studies, \\ CUSAT, Kalamassery, Kerala, India
}

\begin{abstract}
Every year huge sums of fund are transferred out of developing countries illegally including India. These illicit financial flows drain the resources from the country which could be otherwise used to finance the public infrastructure. The impact of illicit financial flows is a reduction in domestic expenditure and investment, both public and private. The only way to remove the growth of illicit financial frauds is the setting up of a robust risk management system at every sector. Effective implementation of anti fraud practices in every industry and an efficient governance system must also be in place to control the financial fraud. This paper points out the scenario of financial frauds and illicit financial flows to India.
\end{abstract}

Keywords- Financial Fraud, Illicit Financial Flows, Financial Fraud Management, Indian Economy

\section{INTRODUCTION}

The Indian economy is considered one of the largest upcoming economies of the world with innovation and utilization of latest information and communication technology in every sphere. With the increase in usage of the latest technology, various threats and illegal activities have also emerged giving rise to financial frauds and illicit financial flows in India. Financial fraud has been one of the key concerns in India as it adversely affects the economy as a whole. Within that banking frauds are on the rise especially in the case of large value frauds which had a detrimental impact on the financial position of the country. Risks are inherent in every sector but with the rising number of fraud cases make the regulators maintain a proper system for regulating the financial frauds in India. Robust financial risk management requires an effective system of internal controls that must be clearly defined and implemented across the banking industry to reduce fraud risk and also an effective assessment approach in managing financial risk.

According to the Financial Stability Report (June 2018), there is a steady growth rate in the total number of frauds reported during the year 2017-18 (chart 1a) which contributes an increase in the card/internet banking related frauds.

\author{
Sreelakshmi D \\ Assistant Professor (on contract) \\ Self Financing Department of Commerce \\ St.Albert's College, Ernakulam, Kerala, India
}

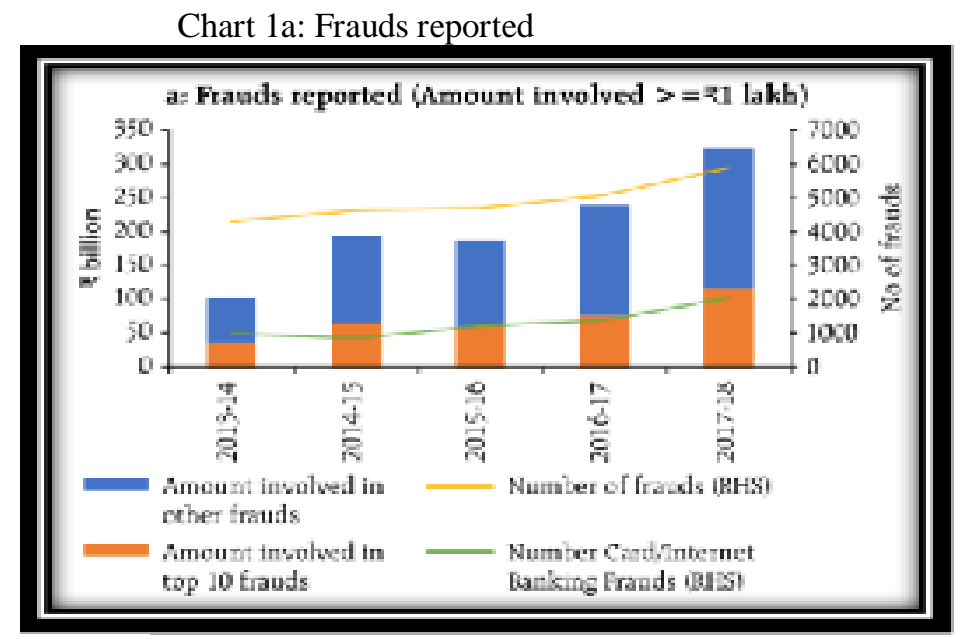

Source: RBI

In India yearly a huge amount of money is transferred illegally which could otherwise be used for funding public infrastructure and help the Indian economy in strengthening. Many of the activities which generate illicit funds are criminal; and while financial crimes like money laundering, corruption, and tax evasion are damaging to the country. The proceeds from transnational organized crimes such as trafficking of humans, drugs, firearms, and environmental resources (wildlife and timber); product counterfeiting, migrant smuggling, and cybercrime are considered a source of illicit funds. The activities giving rise to such proceeds will often take place in developing countries but the proceeds will only materialize once the products of such economic activity across borders. ${ }^{1}$ The rising financial fraud and illicit financial flows make up the reason for analyzing the present study. The study will be able to make an insight into the actual problems that exist in the present scenario of the financial sector in India.

\section{OBJECTIVES OF THE STUDY}

The study intends to analyze the following objectives: 


\section{International Journal of Engineering Applied Sciences and Technology, 2020 \\ Vol. 5, Issue 7, ISSN No. 2455-2143, Pages 145-147 \\ Published Online November 2020 in IJEAST (http://www.ijeast.com)}
i. To describe the present scenario of financial fraud and illicit financial flows in India.
ii. To describe the major financial frauds in India.
iii. To understand the financial risk management in India.

\section{FINANCIAL FRAUD AND ILLICIT FINANCIAL FLOWS IN INDIA}

Global Financial Integrity report estimated that illicit global financial flows from developing countries including India are rising at an average rate of $9.4 \%$ every year. GFI study has also announced that the illicit fund flowing out of India was more than $\$ 439$ billion between 2002 and 2012. India has been fighting against the flow of illicit financial funds for decades and much of these funds were kept in different forms within India including real estates, gold, and even cash. A big amount is also sent abroad through various financial channels.

Under the Indian Income Tax Act, 1961, the country's tax base is defined as "all incomes from whatever sources derived". However, if the persons or group concerned are non-resident, then only that income, which is earned in India falls under tax base or can be taxed; what accrues to them outside India is not taxable in India. Since the early 1990s when the Indian economy opened up, the scale and magnitude of its integration with the world economy have grown significantly. India, labor-abundant, and rich in natural resources, with a huge market, has attracted many foreign corporations' attention. As of now, there has been a lofty increment in the inflows of Foreign Direct Investment (FDI) to India. With more prominent joining of the homegrown economy with the world economy, issues of worldwide tax assessment have gained a ton of hugeness in the area of policymaking. A stressing highlight of the FDI coming to India is that over 53\% of it originates from low duty wards, especially Mauritius, Singapore, UAE, and Cyprus. Consequently, there is an extent of control and duty base disintegration when FDI streams originate from such non-straightforward wards. This is especially stressing for India that depends to a critical degree on organization charge. Company charge assortments in India from 1980 onwards have been expanding, and in 2011 it remained at around $3 \%$ of GDP and $34.6 \%$ of complete duty income. This rate is a lot of lower for the OECD nations. Subsequently, charge base disintegration by MNCs has more noteworthiness for India.

\section{MAJOR FINANCIAL FRAUDS IN INDIA}

- Satyam Scam: Also known as India's Enron Scandal in 2009 revolves around Satyam Computers Services Ltd. the IT company had misrepresented and manipulated their accounts of over 14,000 crore rupees.

- Coalgate Scam: The coal allocation scam or 'Coalgate' was a political scandal that surfaced in 2012 when the
UPA government was in power when CAG accused the government of illegally allocating 194 coal blocks between 2004 and 2009 with a scam amount to Rs. 1.86 lakh crore.

- Vijay Mallya: In 2016, Vijay Mallya absconded the country after being accused of fraud and money laundering and sought refuge in the UK. He allegedly owes various banks over Rs. 9,000 crores, which he had taken as a loan to keep his defunct Kingfisher airlines from failing.

- $\quad$ Punjab National Bank Scam: A major banking fraud was uncovered in the Punjab National Bank in 2018 in which several senior officials were found to be involved. The scam has been the biggest fraud in India's banking history is concerned. PNB authorities recorded an objection with the CBI against three organizations and four individuals that included Nirav Modi and Mehul Choksi, guaranteeing they had swindled the bank and caused lost Rs. 280 crore, yet modified it later to more than Rs. 13,000 crore.

The impact of financial fraud on the banking systems can bring down the confidence and damage the economic stability of the country. It can also undermine the RBI's role and political upheavals. The advancements in technology have also been a factor that contributed to the rising financial frauds. Therefore India must ensure an efficient financial fraud management system to ensure smooth conduct of the banking business as well as to reduce the fraudulent practices.

\section{FINANCIAL FRAUD RISK MANAGEMENT IN INDIA}

Currently, there are certain Anti Fraud Legislations in India that prevent fraudulent practices. They are:
$\checkmark$ Indian Contract Act of 1872
$\checkmark$ Indian Penal Code
$\checkmark$ Prevention of Corruption Act
$\checkmark$ Prevention of Money Laundering Act
$\checkmark$ Companies (Amendment)Act of 2017
$\checkmark$ Clause 49 of the Listing Agreement
$\checkmark$ CARO 2003

Other Indian laws aim to protect the companies from fraud such as the Prevention of Corruption (Amendment) Act, 2011, the Whistleblowers Protection Act, 2011, the Right to Information Act, 2005 (RTI), the Information Technology Act 2000 (IT Act), and the Prevention of Money Laundering Act, 2002 (PMLA) (Indian Fraud Survey, 2014).

As an administration activity, the National Payment Corporation of India has executed a Real-time Fraud Risk Monitoring and Management arrangement (FRM) for extortion discovery and counteraction. This structure is offered for all online items offered by NPCI and they likewise screen ATM, POS, E-com, UPI, and RuPay Visas. 


\section{International Journal of Engineering Applied Sciences and Technology, 2020 \\ Vol. 5, Issue 7, ISSN No. 2455-2143, Pages 145-147 \\ Published Online November 2020 in IJEAST (http://www.ijeast.com)}

\section{CONCLUSION}

Indians are turning out to be wealthier a seemingly endless amount of time after year. The Hurun Global Rich List of 2015 says that India has taken the main three of the tycoon's rundown unexpectedly; India added 27 very rich people since 2014 to take the absolute to 97 , which has supplanted Russia and sits behind USA and China who lead by a wide edge with 537 and 430 individually. A large number have earned their cash through enterprise, industry, and sharp business astuteness, yet some will have earned their riches through criminal operations that tear the creases that hold our social orders together. In the two cases, most will have attempted to pay as meager assessment on their riches as conceivable utilizing legitimate, lawfully questionable, and unlawful "riches the board" structures. The world is attempting to separate between these illicit frameworks and to make a framework that works for all degrees of society. The OECD's Automatic Exchange of Financial Information between nations is a decent advance forward, yet there are worries that, due to specific necessities of the framework and the need to build up a critical two-sided deal organization to encourage the trading of data, it may not profit creating nations in the close or medium-term, worsening worldwide disparity.

The small sum pronounced during the plan is a sharp pointer of the amount more the legislature must do to target unlawful assets. In the principal administrative advance, India has been attempting to alter laws that tackle pay off under its responsibility to the UN Convention Against Corruption (UNCAC). Unfortunately the enactment couldn't be ordered. The Prevention of Bribery of Foreign Public Officials and Officials of Public International Organizations Bill of 2011 slipped by in the Parliament as lawmakers decided not to proceed onward it. A proposition for a new bill to sanction the UNCAC and tackle pay off is being readied now. The Indian government needs to move from well meaning goals to solid activity in the event that it needs results, and those activities must be predicated on an all encompassing evaluation of how a given nation is defenseless against the loss of capital through unlawful outpourings. While enactment is fundamentally received piecemeal, the pieces ought to be essential for a bigger arrangement by governments to stem unlawful streams to revive their economies.

\section{REFERENCES}

1) UNODC (2010). The Globalization of Crime, A Transnational Organized Crime Threat Assessment. Retrieved from http://www.unodc.org/documents/dataand-analysis/tocta/TOCTA_Report_2010_low_res.pdf
2) Mahajan, Rohit; Sharma, Veena. (2014), Fraud Risk Management - providing insight into fraud prevention, detection, and response, Deloitte, (Pg1-12).

3) Mahajan, Rohit; Karthik, K. V. (2015), India Banking Fraud Survey, Deloitte Edition II, (Pg1-36).

4) Singh, Charan. (2016), Frauds in the Indian Banking Industry, IIMB-Working Paper, N0. 505, (Pg1-24).

5) India, Reserve, Bank. (2018), Financial Stability Report (18), Mumbai: Financial Stability Unit, RBI, (Pg1-100). Retrieved from: https://www.rbi.org.in

6) Deeksha Upadhyay, Deeksha. (2018), Banking Scams in India, Journal of Banking and Insurance Law, 1(2), (Pg713).

7) Bedi, Nikhil; Karthik, K. V. (2018), India Banking Fraud Survey, Deloitte Edition III, (Pg1-30).

8) Jeyanthi, Mary. P; Mansurali. A; Harish. V; Krishnaveni. V. D. (2020), Significance of Fraud Analytics in Indian Banking Sectors, Journal of Critical Reviews, 7(4), (Pg209-213).

9) Deloitte, India Fraud Survey. (2014), Retrieved from: https://www2.deloitte.com/content/dam/Deloitte/in/Docu ments/finance/in-finance-annual-fraud-survey-noexp.pdf (deloitte.com) 